\title{
Review \\ Omalizumab: An Optimal Choice for Patients with Severe Allergic Asthma
}

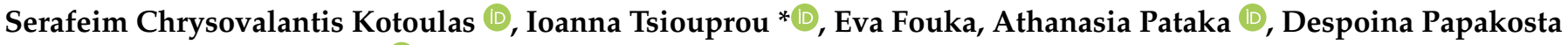 \\ and Konstantinos Porpodis
}

Citation: Kotoulas, S.C.; Tsiouprou, I.; Fouka, E.; Pataka, A.; Papakosta, D.; Porpodis, K. Omalizumab: An Optimal Choice for Patients with Severe Allergic Asthma. J. Pers. Med. 2022, 12, 165. https://doi.org/ 10.3390/jpm12020165

Academic Editor: Giorgio

Walter Canonica

Received: 14 October 2021

Accepted: 30 December 2021

Published: 26 January 2022

Publisher's Note: MDPI stays neutral with regard to jurisdictional claims in published maps and institutional affiliations.

Copyright: (C) 2022 by the authors. Licensee MDPI, Basel, Switzerland. This article is an open access article distributed under the terms and conditions of the Creative Commons Attribution (CC BY) license (https:// creativecommons.org/licenses/by/ $4.0 /)$.
Pulmonary Department, Medical School, Aristotle University of Thessaloniki, "G. Papanikolaou" General Hospital, Exohi, 57010 Thessaloniki, Greece; akiskotoulas@hotmail.com (S.C.K.); evafouka@auth.gr (E.F.); patakath@yahoo.gr (A.P.); depapako@gmail.com (D.P.); kporpodis@yahoo.gr (K.P.)

* Correspondence: joanna_tsi@hotmail.com

\begin{abstract}
Omalizumab is the first monoclonal antibody that was globally approved as a personalized treatment option for patients with moderate-to-severe allergic asthma. This review summarizes the knowledge of almost two decades of use of omalizumab to answer some important everyday clinical practice questions, concerning its efficacy and safety and its association with other asthma-related and drug-related parameters. Evidence suggests that omalizumab improves asthma control and reduces the incidence and frequency of exacerbations in patients with severe allergic asthma. Omalizumab is also effective in those patients in reducing corticosteroid use and healthcare utilization, while it also seems to improve lung function. Several biomarkers have been recognized in predicting its efficacy in its target group of patients, while the optimal duration for evaluating its efficacy is between 16 and 32 weeks.
\end{abstract}

Keywords: omalizumab; severe allergic asthma; $\operatorname{IgE}$

\section{Introduction}

Asthma is a heterogeneous disease with different identifiable clusters of demographics, clinical and/or pathophysiological characteristics, often referred to as asthma phenotypes [1]. The most common asthma phenotype is allergic asthma, which counts for up to $80 \%$ of childhood asthma and more than $50 \%$ of adult asthma cases [2,3]. Nowadays, an improved understanding of the pathophysiology of asthma and the identification of different phenotypes led to the development of personalized, phenotype-guided treatments [4-6].

Omalizumab, a recombinant humanized monoclonal antibody which specifically binds to the C epsilon3 domain of immunoglobulin ( $\mathrm{Ig}) \mathrm{E}$ was marketed in the dawn of the 21st century and was the first among many of such treatments [7]. Omalizumab is currently suggested in patients aged six years or older with difficult-to-treat to severe persistent allergic asthma according to the Global Initiative for Asthma (GINA) guidelines, who fulfill one or more of the following criteria: sensitization to inhaled allergen(s) on a skin prick testing or specific IgE.; and body weight within a local dosing range, and more than a specified number of exacerbations within the last year, despite a daily high dose of inhaled corticosteroids, plus a long-acting inhaled beta2-agonist $[1,8,9]$.

This review consolidates the experience of two decades of using this personalized treatment for patients with severe allergic asthma, answering some questions from daily clinical practice about the effectiveness of omalizumab in improving asthma symptoms, reducing corticosteroid use, reducing exacerbation rate and healthcare utilization. The purpose of this review is to describe omalizumab's safety and its association with biomarkers and lung function and to define the duration of its administration to evaluate its effectiveness. 


\section{Omalizumab's Efficacy on Asthma Symptom Improvement}

Several tools are available for monitoring asthma control, such as validated questionnaires (asthma control test (ACT) [10], an asthma control questionnaire (ACQ) [11], and an asthma quality of life questionnaire (AQLQ) [12], etc. [10-16].

Ayres et al. proved that out of a total of 312 patients with poorly controlled, severe, allergic asthma, those who were treated with omalizumab plus the best standard care experienced a significant improvement in asthma symptom control compared to the control group, where the best standard care was offered (Table S1) [17]. In another randomized controlled trial, which included 400 asthmatic patients, Bousquet et al. demonstrated that asthma control, measured by ACQ score was significantly improved both at 16 and at 32 weeks in patients who received omalizumab compared to controls (Table S1) [18]. Moreover, the results of several early clinical trials [19-24], as well as of later ones, [25,26] indicated symptom improvement in asthmatic patients, both children and adults, who received omalizumab, compared to the controls, although those results were not always statistically significant. Nevertheless, a systematic review with meta-analysis which combined these studies concluded that in a total of 3429 participants, asthmatic patients who received omalizumab exhibited a statistically significant improvement not only in asthma control scales but also in quality-of-life scales, such as AQLQ.; compared to the controls [27]. The same findings were also demonstrated by another systematic review with meta-analysis, which included three randomized, double-blind, placebo-controlled studies, that enrolled 1412 patients with moderate or severe allergic asthma [28].

Apart from clinical trials, there are also several observational, every-day clinical practice studies which also evaluated the efficacy of omalizumab in asthma symptom control. Barnes et al. demonstrated that both asthma control, measured by ACT and quality of life, measured by AQLQ.; were significantly improved in asthmatic patients after the initiation of omalizumab both at 16 and at 52 weeks [29]. Similar results were also published by Deschildre et al., who used GINA criteria to assess asthma control in children with asthma after the initiation of omalizumab (Table S1) [30]. Researchers found that the initiation of omalizumab in patients with severe allergic asthma led to a significant improvement in both daily and nightly symptoms as well as in different asthma symptom scales such as AQLQ.; mini-AQLQ and ACT [31-33]. On the other hand, Nopp et al., in a very small-scale study, reported that 8 out of 18 asthmatic patients who were treated with omalizumab for 6 months still exhibited asthma symptom improvement 3 years after the discontinuation of omalizumab [34]. However, another study which included 943 patients with asthma reported a significant reduction in (a) daily symptoms, (b) activity limitation, (c) night symptoms, (d) night awakenings due to asthma and (e) the need for reliever medication, after the initiation of omalizumab both at 12 and at 24 months. In the same study, the findings from both ACT and ACQ scales were also significantly improved $[34,35]$.

\section{Effectiveness of Omalizumab in Reducing Corticosteroid Use}

Alongside standard treatment with ICS.; patients often need to be treated with oral corticosteroids (OCS) to achieve better asthma control [35-44]. Novel therapy strategies aim to reduce the use of corticosteroids to eliminate possible adverse effects [45-53].

Busse et al. found that ICS administration was reduced by $75 \%$ in patients with severe asthma 28 weeks after the initiation of omalizumab, which was significantly greater than the $50 \%$ reduction in the control group (Table S1) [24]. Similar results about ICS reduction were also reported by another clinical trial at 32 weeks after omalizumab initiation $(57.2 \%$ of the patients who received omalizumab vs. $43.3 \%$ of the placebo group, $p<0.05$ ) [21]. Moreover, the effect of omalizumab on ICS reduction was predicted by the Archimedes asthma model for US patients aged 12 and older with moderate-to-severe persistent allergic asthma [54-58]. Apart from ICS dosage reduction, omalizumab seems to be even more effective in OCS dosage reduction and/or discontinuation [56,59-63]. The beforementioned effects of omalizumab in corticosteroid use have also been confirmed by four systematic reviews with meta-analyses $[8,27,64,65]$. 
In addition to clinical trials, the impact of omalizumab on corticosteroids use in severe allergic asthma has also been demonstrated by several observational real-life studies. The initiation of omalizumab resulted in significant reduction in ICS dosage in several studies [30,32,33,66,67], while in another study, its discontinuation led to a significant increase in prescribed ICS dosage [34]. Furthermore, the initiation of omalizumab had the same effect in OCS usage, as it led to significant OCS dosage reduction or discontinuation in several studies [29,35,68-72], while in another study both ICS and OCS reduction was observed in patients with severe allergic asthma who were treated with omalizumab for seven years [73].

\section{Efficacy of Omalizumab in Reducing the Rate of Asthma Exacerbations}

Severe exacerbations may occur even in patients with mild or well-controlled asthma symptoms as a patient's risk of exacerbations may be independent of the level of symptom control [73-75]. More importantly, exacerbations were proved fatal on many occasions [76-80]. Therefore, a successful therapeutic strategy should prevent asthma exacerbations.

Omalizumab resulted in the reduction of the asthma exacerbation rate in numerous clinical trials during the last two decades, both in adults and in children [17-26,55,60,81-84]. In two clinical trials, the exacerbation rate was significantly reduced in the omalizumab group (between 35-45\% reduction) compared to the control group [18,21]. Ayres et al. reported 1.12 exacerbations per patient per year in the omalizumab group, which was significantly lower than the 2.86 exacerbations per patient per year in the control group (Table S1) [17]. Solèr et al., in one of the first clinical trials of omalizumab which included 546 participants, reported that both the number of exacerbations per patient during the stable-steroid phase $(0.28$ in the group who received omalizumab vs. 0.66 in the placebo group) as well as during the steroid-reduction phase ( 0.36 in the group who received omalizumab vs. 0.75 in the placebo group) and the number of patients needed to treat in order to avoid an exacerbation were significantly lower in the omalizumab group compared to the control group (35 in the group who received omalizumab vs. 83 in the placebo group during the steroid-reduction phase/43 in the group who received omalizumab vs. 81 in the placebo group during the steroid-reduction phase) (Table S1) [22]. On the other hand, there are also clinical trials in which the asthma exacerbation rate was not significantly reduced in the omalizumab group compared to the control group $[57,85,86]$. However, several systematic reviews with meta-analyses have concluded that omalizumab significantly reduces the asthma exacerbation rate compared to a placebo [27,28,64,87]. Moreover, another randomized controlled trial has proved that omalizumab is more effective in preventing asthma exacerbations in fall compared to an inhaled corticosteroid boost [88].

Apart from clinical trials, omalizumab has also been shown to be effective in the reduction of the asthma exacerbation rate in numerous observational real-life studies [29-35,66,68,73,8998]. Barnes et al. and Deschildre et al. reported a significant reduction in asthma exacerbations after the initiation of omalizumab from 3.67 to 1.70 per patient per year and from 4.40 to 1.25 per patient per year, respectively (Table S1) [29,30]. Two more studies reported a significant reduction in asthma exacerbations per patient per year after the initiation of omalizumab (from 5.00 to 0.63 and from 5.70 to 1.90, respectively) [32,68]. Three more studies reported a significant reduction in the asthma exacerbation rate between $62 \%$ and $82 \%[31,33,66]$. Nopp et al. found that 16 out of 18 patients who discontinued omalizumab still had fewer exacerbations during nights, even 3 years after the drug withdrawal [34]. The effect of omalizumab's discontinuation on the increase of exacerbations was confirmed by two recently published studies $[99,100]$.

\section{Omalizumab's Efficacy on Healthcare Utilization}

Omalizumab has been shown to be effective in reducing the rate of emergency care visits and hospitalizations $[77,79,101-114]$. A clinical trial reported that patients treated with omalizumab suffered from 4.92 of such events per year compared to the 9.76 of such events per year in the control group [17]. Humbert et al. showed that, at 28 weeks, omalizumab 
significantly reduced emergency care visits and hospitalizations compared to the control group ( 0.24 vs. 0.43 and 0.125 vs. 0.25 , respectively) [19]. Moreover, Bousquet et al. have proved a significant reduction in emergency care visits by $60 \%$ and in hospitalizations by $67 \%$ in the omalizumab group compared to the control group [18].

Real-life studies have demonstrated a significant reduction in emergency care visits and hospitalizations after the initiation of omalizumab which varied between 51-90.8\% and $28-95 \%$, respectively $[30,31,56,66,115-117]$. Other studies also reported a significant reduction in hospitalizations from $1.07-5.93$ per patient per year to $0.10-2.75$ per patient per year and in emergency care visits from 1.13-1.52 per patient per year to $0.29-0.46$ per patient per year after the initiation of omalizumab $[29,61,96]$. Furthermore, Braunstahl et al., in the context of "eXpeRience registry", which included 943 patients with asthma, reported a reduction in the unscheduled asthma-related visits in a healthcare provider from 6.2 per patient per year to 1.0 per patient per year and to 0.5 per patient per year at 12 and 24 months, respectively (Table S1) [35]. Other studies have demonstrated that after four-to-five years from the initiation of omalizumab almost no patient needed an asthmarelated hospitalization $[32,94,117]$, while Molimard et al. reported that the reduction in emergency care visits and hospitalizations after the initiation of omalizumab is irrespective of the reduction or the cessation of corticosteroids (Table S1) [68]. In addition to hospital admission, omalizumab also appears to significantly reduce the duration of hospitalization and the cost per hospital stay [118-120].

\section{Safety Outcomes}

Several asthma medications, and especially corticosteroids, present a wide spectrum of potentially serious adverse effects, particularly OCS in prolonged administration [45-49, $121,122]$, but also in shorter use $[50,123]$. Omalizumab has been studied thoroughly during the last two decades and it seems to be a well-tolerated add-on treatment. Adverse events include anaphylaxis, malignancy, and symptoms such as serum sickness and eosinophilic conditions [8].

Clinical studies provide data on the safety and tolerability profile of omalizumab therapy in adults with asthma, urticaria, food allergies and allergic rhinitis $[17,18,21,24,26$, $54,82,85,86,124-133]$. The most common adverse events that were attributed to omalizumab in various clinical trials were local reactions to the injection site (i.e., redness and swelling), urticaria, erythema, headache, ear symptoms, sinusitis, nasopharyngitis, bronchitis, asthma, infections such as upper respiratory tract infection, influenza, pneumonia, gastrointestinal infections (appendicitis and intestinal geohelminth infection) and serum disease with or without anaphylaxis (Table S2) $[19,25,113,133-140]$. No adverse effects were revealed by hematology and biochemistry laboratory measurements [138,141]. There was no adverse effect regarding electrocardiographic data $[138,141]$. Omalizumab seems to be related with a lower risk for anaphylaxis compared to other monoclonal antibodies for asthma treatment, but when anaphylaxis occurred, patients with asthma who were treated with omalizumab seemed to be at greater danger for life-threatening reactions than those who are treated with omalizumab for urticaria [142]. Most adverse events are mild to moderate and usually do not lead to drug discontinuation $[20,83,139,143,144]$. A systematic review with meta-analysis of 3429 patients revealed that the patients who received omalizumab had a comparable percentage of side effects and serious side effects with the control group ( $1.3 \%$ vs. $1.5 \%$ and $3.8 \%$ vs. $5.3 \%$, respectively). Patients in the omalizumab group exhibited a significantly higher percentage of local reactions in the injection site compared to the placebo group (19.9\% vs. $13.2 \%, p=0.002)$ [27]. There were no other significant differences between the two groups in separate adverse events such as urticaria, anaphylaxis, cardiovascular events, malignancies, or deaths [27]. A disproportionality analysis of the WHO's VigiBase pharmacovigilance database showed that omalizumab may be associated with a significantly higher risk of malignancies. However, this result refers to a disproportionality analysis and it should be interpreted with caution, as retrospective and prospective cohorts 
are needed to confirm the findings [145]. Moreover, cases of death are rare and not directly attributable to omalizumab [138].

Observational studies were conducted to assess the adverse effects of this monoclonal antibody. Overall, the safety profile was consistent with the current label. Newly recognized adverse effects such as malignant neoplasms, relapsing herpes labialis, pyrexia, fatigue, chest pain, nausea, arthralgia, myalgia, type 1 hypersensitivity, angioedema, metrorrhagia and abortion were reported (Table S2) [146-153].However, the relative risk ratio for these adverse events seems to be very low $[32,70,73,92,154-164]$. In several observational studies the percentage of adverse events varies between $2.5 \%$ and $32.9 \%[31,33,35,66,71$, $94,95,97,115,165,166]$, the percentage of serious adverse events varies between $0.0 \%$ and $16.1 \%[30,33,66,71,95,97,115,167]$ and the rate of drug discontinuation due to an adverse event varies between $0.0 \%$ and $12.5 \%$ [30,33,35,94,115,165-167]. Long-term studies may need to adequately assess the risk of malignancy.

\section{Association of Biomarkers with Outcomes of Omalizumab-Treated Patients}

Several biomarkers have been identified and studied with respect to responsiveness of drug therapy in T2 high asthma, such as: total IgE.; periostin, blood eosinophils and FeNO.

Serum levels of total IgE were found increased 16 and 28 weeks after the initiation of omalizumab in patients with asthma [24], while they were decreased after seven years of use in another study [73]. Lowe et al. analyzed the data from previously published studies and found that once long-term observations were included, the models allowing IgE production to decrease fitted with their analysis [168]. Free IgE levels were decreased by $89-99 \%$ after the initiation of omalizumab $[22,24]$, and this reduction was associated with a lower rate of exacerbations after two years of treatment [169]. Omalizumab has also been found to decrease the sensitivity to $C D$ antigens of the responsible allergens after long-term use irrespective of total or specific IgE levels [34]. Apart from IgE.; which is an obvious target for omalizumab, other biomarkers such as T-helper-type-2 (Th2) inflammation biomarkers such as blood and/or sputum eosinophils and fraction of exhaled nitric oxide (FeNO) have been linked with omalizumab $[92,93,170]$. Serum periostin was also studied as a biomarker, as it is generated in response to IL-13 and serves as a marker of Th2-related inflammation $[170,171]$. There are some studies which have not found an association between these biomarkers and the response to omalizumab $[92,93,170]$. However, the majority of the studies demonstrate such an association, with the high levels of blood eosinophils and $\mathrm{FeNO}$ and, to a lesser degree, of serum periostin to be associated with higher response rates to the treatment with omalizumab in terms of symptom and exacerbation control, OCS usage, hospital admissions and lung function [90,169,171-175]. Moreover, histological and immunological studies of the airways have shown that omalizumab reduces the mucosal concentration of IgE and the tissue eosinophil cell density [176]. Furthermore, the use of FeNO measurement to specify omalizumab responders may decrease the expected per-patient cost [177]. Those results have led the American Thoracic Society (ATS) and the European Respiratory Society (ERS) to recommend blood eosinophil count and FeNO as biomarkers with a high value for the increased response to omalizumab and periostin as a biomarker with a low value [178]. Nevertheless, novel histological, serological and molecular studies have identified additional biomarkers which are predictive of a response to omalizumab such as bronchial protein galectin-3 [179,180], serum pregnancy-associated plasma protein-A (PAPP-A) [181], serum C4Ma3, a degradation marker of the inflammationprotective collagen 4 (COL4A3) [182] and CD3E antigen of immune cells [178].

\section{Omalizumab and Lung Function}

Patients with severe allergic asthma often experience a significant decline in lung function. Despite the fact that some studies have not found a significant improvement in forced expiratory volume in $1 \mathrm{~s}$ (FEV1) after the initiation of omalizumab [118,166,183-189], the majority of the studies have exhibited a significant improvement in FEV1 after the initiation of omalizumab in asthmatic patients both as a whole $[17,29,32,33,59,60,67,73,81,86,119,152$, 
153,158,162,173,190-198], and in specific groups such as children [199], obese patients [200], patients with fixed airway obstruction [201], patients with various co-morbidities [202], and even non-atopic patients with asthma [87]. Similar improvements after the initiation of omalizumab have also been observed in forced vital capacity (FVC) [33,203], FEV1/FVC ratio [59,73], peak expiratory flow (PEF) [19,86,204-207], small airway flows (FEF25-75) [199,208], and airway resistances [209-212]. Interestingly, omalizumab also seems to improve hyperinflation due to air trapping measured by the residual volume to total lung capacity (RV/TLC) ratio [213]. Furthermore, it has been demonstrated that omalizumab reduces the response to the methacholine and adenosine $5^{\prime}$-monophosphate (AMP) challenge test by increasing the provocative concentration required to produce a $20 \%$ fall in FEV1 and increases the tolerability of asthmatic patients to longer allergen exposure [211,214-216]. Finally, FEV1 has served as a predictor of the response to omalizumab with lower values leading to better response rates [60,217-221].

\section{Optimal Duration of Treatment}

It is crucial to determine a certain duration of omalizumab administration to assess its efficacy. Various criteria have been proposed, such as the characteristics of patients (age etc.) and biomarkers (IgE levels, FeNO etc.).

The minimum period for omalizumab effectiveness assessment was four weeks in one study [24]. According to most studies, this period varies between 16-20 weeks to 26-32 weeks [18-22,24,29-33,63,66,68,93]. There are also studies which evaluated omalizumab for an even longer period, although these studies were either early clinical trials [17], or observational studies which lasted longer mainly because they tried to evaluate omalizumab's safety profile $[29,30,32-35,73,93]$. Ayres et al., Barnes et al., Deschildre et al. and Humbert et al. evaluated omalizumab for or up to 52 weeks $[17,29,30,93]$. Braunstahl et al. and Tzortzaki et al. assessed omalizumab for a period between one and two years and one and four years, respectively [33,35]. Moreover, other researchers used even longer periods, such as three, four, seven or up to nine years [32,34,73]. Two systematic reviews with meta-analyses reported that the studies which they included, evaluated omalizumab for time periods which varied between 16 and 58 weeks $[27,28]$. Nevertheless, the evidence suggests that the optimal duration of omalizumab administration in order to assess its efficacy varies between 16 and 32 weeks.

\section{Conclusions}

Omalizumab has been consistently proved effective in improving asthma symptom control irrespective of the scale that was used to measure its efficacy. It is also effective in reducing corticosteroid usage both inhaled and systematic, thus minimizing the catastrophic adverse effects of corticosteroids in patients with asthma. Omalizumab also reduces the exacerbation rate in patients with severe allergic asthma and the healthcare utilization. Overall, omalizumab presents a rather safe profile, even though long-term cohort studies are necessary to evaluate its relative risk, if there is any, for some serious adverse effects such as malignancies and abortions. Omalizumab also seems to improve various parameters of lung function. Finally, several biomarkers can be used to assess its efficacy or the need for its discontinuation, with the optimal duration of administration for this evaluation being set at 16-32 weeks.

Supplementary Materials: The following supporting information can be downloaded at: https: / /www.mdpi.com/article/10.3390/jpm12020165/s1, Table S1: Efficacy of omalizumab in patients with severe allergic asthma; Table S2: Common adverse events of the use of omalizumab in asthmatic patients.

Author Contributions: S.C.K., I.T., E.F., A.P., D.P. and K.P. contributed equally to this manuscript, as far as conceptualization, investigation, writing-original draft, review and editing are concerned. All authors have read and agreed to the published version of the manuscript.

Funding: This review article received no external funding. 


\section{Institutional Review Board Statement: Not applicable.}

Informed Consent Statement: Not applicable.

Conflicts of Interest: The authors declare no conflict of interest.

\section{References}

1. Global Initiative for Asthma. Global Strategy for Asthma Management and Prevention. 2021. Available online: www.ginasthma. org (accessed on 10 October 2021).

2. Johansson, S.G.; Hourihane, J.O.; Bousquet, J.; Bruijnzeel-Koomen, C.; Dreborg, S.; Haahtela, T.; Kowalski, M.L.; Mygind, N.; Ring, J.; van Cauwenberge, P.; et al. A revised nomenclature for allergy. An EAACI position statement from the EAACI nomenclature task force. Allergy 2001, 56, 813-824. [CrossRef]

3. Akar-Ghibril, N.; Casale, T.; Custovic, A.; Phipatanakul, W. Allergic endotypes and phenotypes of asthma. J. Allergy Clin. Immunol. Pract. 2020, 8, 429-440. [CrossRef] [PubMed]

4. Wenzel, S.E. Asthma phenotypes: The evolution from clinical to molecular approaches. Nat. Med. 2012, 18, 716-725. [CrossRef]

5. Bel, E.H. Clinical phenotypes of asthma. Curr. Opin. Pulm. Med. 2004, 10, 44-50. [CrossRef] [PubMed]

6. Moore, W.C.; Meyers, D.A.; Wenzel, S.E.; Teague, W.G.; Li, H.; Li, X.; D’Agostino, R., Jr.; Castro, M.; Curran-Everett, D.; Fitzpatrick, A.M.; et al. Identification of asthma phenotypes using cluster analysis in the Severe Asthma Research Program. Am. J. Respir. Crit. Care Med. 2010, 181, 315-323. [CrossRef] [PubMed]

7. Easthope, S.; Jarvis, B. Omalizumab. Drugs 2001, 61, 253-260. [CrossRef]

8. Normansell, R.; Walker, S.; Milan, S.J.; Walters, E.H.; Nair, P. Omalizumab for asthma in adults and children. Cochrane Database Syst. Rev. 2014, CD003559. [CrossRef]

9. Rodrigo, G.J.; Neffen, H. Systematic review on the use of omalizumab for the treatment of asthmatic children and adolescents. Pediatr. Allergy Immunol. 2015, 26, 551-556. [CrossRef]

10. Nathan, R.A.; Sorkness, C.A.; Kosinski, M.; Schatz, M.; Li, J.T.; Marcus, P.; Murray, J.J.; Pendergraft, T.B. Development of the asthma control test: A survey for assessing asthma control. J. Allergy Clin. Immunol. 2004, 113, 59-65. [CrossRef]

11. Juniper, E.F.; O’Byrne, P.M.; Guyatt, G.H.; Ferrie, P.J.; King, D.R. Development and validation of a questionnaire to measure asthma control. Eur. Respir. J. 1999, 14, 902-907. [CrossRef]

12. Juniper, E.F.; Guyatt, G.H.; Epstein, R.S.; Ferrie, P.J.; Jaeschke, R.; Hiller, T.K. Evaluation of impairment of health related quality of life in asthma: Development of a questionnaire for use in clinical trials. Thorax 1992, 47, 76-83. [CrossRef] [PubMed]

13. Schatz, M.; Sorkness, C.A.; Li, J.T.; Marcus, P.; Murray, J.J.; Nathan, R.A.; Kosinski, M.; Pendergraft, T.B.; Jhingran, P. Asthma Control Test: Reliability, validity, and responsiveness in patients not previously followed by asthma specialists. J. Allergy Clin. Immunol. 2006, 117, 549-556. [CrossRef] [PubMed]

14. Juniper, E.F.; Bousquet, J.; Abetz, L.; Bateman, E.D. Identifying 'well-controlled' and 'not well-controlled' asthma using the Asthma Control Questionnaire. Respir. Med. 2006, 100, 616-621. [CrossRef] [PubMed]

15. Juniper, E.F.; Svensson, K.; Mork, A.C.; Stahl, E. Measurement properties and interpretation of three shortened versions of the asthma control questionnaire. Respir. Med. 2005, 99, 553-558. [CrossRef]

16. Juniper, E.F.; Guyatt, G.H.; Willan, A.; Griffith, L.E. Determining a minimal important change in a disease-specific quality of life questionnaire. J. Clin. Epidemiol. 1994, 47, 81-87. [CrossRef]

17. Ayres, J.G.; Higgins, B.; Chilvers, E.R.; Ayre, G.; Blogg, M.; Fox, H. Efficacy and tolerability of anti-immunoglobulin E therapy with omalizumab in patients with poorly controlled (moderate-to-severe) allergic asthma. Allergy 2004, 59, 701-708. [CrossRef]

18. Bousquet, J.; Siergiejko, Z.; Swiebocka, E.; Humbert, M.; Rabe, K.F.; Smith, N.; Leo, J.; Peckitt, C.; Maykut, R.; Peachey, G. Persistency of response to omalizumab therapy in severe allergic (IgE-mediated) asthma. Allergy 2011, 66, 671-678. [CrossRef] [PubMed]

19. Humbert, M.; Beasley, R.; Ayres, J.; Slavin, R.; Hébert, J.; Bousquet, J.; Beeh, K.M.; Ramos, S.; Canonica, G.W.; Hedgecock, S.; et al Benefits of omalizumab as add-on therapy in patients with severe persistent asthma who are inadequately controlled despite best available therapy (GINA 2002 step 4 treatment): INNOVATE. Allergy 2005, 60, 309-316. [CrossRef] [PubMed]

20. Vignola, A.M.; Humbert, M.; Bousquet, J.; Boulet, L.P.; Hedgecock, S.; Blogg, M.; Fox, H.; Surrey, K. Efficacy and tolerability of anti-immunoglobulin $\mathrm{E}$ therapy with omalizumab in patients with concomitant allergic asthma and persistent allergic rhinitis: SOLAR. Allergy 2004, 59, 709-717. [CrossRef] [PubMed]

21. Holgate, S.T.; Chuchalin, A.G.; Hébert, J.; Lötvall, J.; Persson, G.B.; Chung, K.F.; Bousquet, J.; Kerstjens, H.A.; Fox, H.; Thirlwell, J.; et al. Efficacy and safety of a recombinant anti-immunoglobulin E antibody (omalizumab) in severe allergic asthma. Clin. Exp. Allergy 2004, 34, 632-638. [CrossRef]

22. Solèr, M.; Matz, J.; Townley, R.; Buhl, R.; O’Brien, J.; Fox, H.; Thirlwell, J.; Gupta, N.; Della Cioppa, G. The anti-IgE antibody omalizumab reduces exacerbations and steroid requirement in allergic asthmatics. Eur. Respir. J. 2001, 18, 254-261. [CrossRef] [PubMed]

23. Milgrom, H.; Berger, W.; Nayak, A.; Gupta, N.; Pollard, S.; McAlary, M.; Taylor, A.F.; Rohane, P. Treatment of childhood asthma with anti-immunoglobulin E antibody (omalizumab). Pediatrics 2001, 108, E36. [CrossRef] [PubMed] 
24. Busse, W.; Corren, J.; Lanier, B.Q.; McAlary, M.; Fowler-Taylor, A.; Cioppa, G.D.; van As, A.; Gupta, N. Omalizumab, anti-IgE recombinant humanized monoclonal antibody, for the treatment of severe allergic asthma. J. Allergy Clin. Immunol. 2001, 108, 184-190. [CrossRef] [PubMed]

25. Ohta, K.; Miyamoto, T.; Amagasaki, T.; Yamamoto, M.; 1304 Study Group. Efficacy and safety of omalizumab in an Asian population with moderate-to-severe persistent asthma. Respirology 2009, 14, 1156-1165. [CrossRef]

26. Lanier, B.; Bridges, T.; Kulus, M.; Taylor, A.F.; Berhane, I.; Vidaurre, C.F. Omalizumab for the treatment of exacerbations in children with inadequately controlled allergic (IgE-mediated) asthma. J. Allergy Clin. Immunol. 2009, 124, 1210-1216. [CrossRef] [PubMed]

27. Rodrigo, G.J.; Neffen, H.; Castro-Rodriguez, J.A. Efficacy and safety of subcutaneous omalizumab vs. placebo as add-on therapy to corticosteroids for children and adults with asthma: A systematic review. Chest 2011, 139, 28-35. [CrossRef] [PubMed]

28. Holgate, S.; Bousquet, J.; Wenzel, S.; Fox, H.; Liu, J.; Castellsague, J. Efficacy of omalizumab, an anti-immunoglobulin E antibody, in patients with allergic asthma at high risk of serious asthma-related morbidity and mortality. Curr. Med. Res. Opin. 2001, 17, 233-240. [CrossRef] [PubMed]

29. Barnes, N.; Menzies-Gow, A.; Mansur, A.H.; Spencer, D.; Percival, F.; Radwan, A.; Niven, R. Effectiveness of omalizumab in severe allergic asthma: A retrospective UK real-world study. J. Asthma 2013, 50, 529-536. [CrossRef]

30. Deschildre, A.; Marguet, C.; Salleron, J.; Pin, I.; Rittié, J.L.; Derelle, J.; Taam, R.A.; Fayon, M.; Brouard, J.; Dubus, J.C.; et al. Add-on omalizumab in children with severe allergic asthma: A 1-year real life survey. Eur. Respir. J. 2013, 42, 1224-1233. [CrossRef] [PubMed]

31. Korn, S.; Thielen, A.; Seyfried, S.; Taube, C.; Kornmann, O.; Buhl, R. Omalizumab in patients with severe persistent allergic asthma in a real-life setting in Germany. Respir. Med. 2009, 103, 1725-1731. [CrossRef]

32. Menzella, F.; Galeone, C.; Formisano, D.; Castagnetti, C.; Ruggiero, P.; Simonazzi, A.; Zucchi, L. Real-life efficacy of omalizumab after 9 years of follow-up. Allergy Asthma Immunol. Res. 2017, 9, 368-372. [CrossRef] [PubMed]

33. Tzortzaki, E.G.; Georgiou, A.; Kampas, D.; Lemessios, M.; Markatos, M.; Adamidi, T.; Samara, K.; Skoula, G.; Damianaki, A.; Schiza, S.; et al. Long-term omalizumab treatment in severe allergic asthma: The south-eastern mediterranean "real-life" experience. Pulm. Pharmacol. Ther. 2012, 25, 77-82. [CrossRef] [PubMed]

34. Nopp, A.; Johansson, S.G.; Adédoyin, J.; Ankerst, J.; Palmqvist, M.; Oman, H. After 6 years with Xolair; a 3-year withdrawal follow-up. Allergy 2010, 65, 56-60. [CrossRef]

35. Braunstahl, G.J.; Chen, C.W.; Maykut, R.; Georgiou, P.; Peachey, G.; Bruce, J. The eXpeRience registry: The 'real-world' effectiveness of omalizumab in allergic asthma. Respir. Med. 2013, 107, 1141-1151. [CrossRef] [PubMed]

36. O’Byrne, P.M.; Pedersen, S.; Lamm, C.J.; Tan, W.C.; Busse, W.W.; START Investigators Group. Severe exacerbations and decline in lung function in asthma. Am. J. Respir. Crit. Care Med. 2009, 179, 19-24. [CrossRef]

37. Busse, W.W.; Pedersen, S.; Pauwels, R.A.; Tan, W.C.; Chen, Y.Z.; Lamm, C.J.; O’Byrne, P.M.; START Investigators Group. The inhaled steroid treatment as regular therapy in early asthma (START) study 5-year follow-up: Effectiveness of early intervention with budesonide in mild persistent asthma. J. Allergy Clin. Immunol. 2008, 121, 1167-1174. [CrossRef] [PubMed]

38. Selroos, O.; Pietinalho, A.; Löfroos, A.B.; Riska, H. Effect of early vs. late intervention with inhaled corticosteroids in asthma. Chest 1995, 108, 1228-1234. [CrossRef]

39. Selroos, O. Effect of disease duration on dose-response of inhaled budesonide in asthma. Respir. Med. 2008, 102, 1065-1072. [CrossRef]

40. Chung, K.F.; Wenzel, S.E.; Brozek, J.L.; Bush, A.; Castro, M.; Sterk, P.J.; Adcock, I.M.; Bateman, E.D.; Bel, E.H.; Bleecker, E.R.; et al. International ERS/ATS guidelines on definition, evaluation and treatment of severe asthma. Eur. Respir. J. 2014, 43, 343-373. [CrossRef]

41. Reddel, H.K.; Barnes, D.J.; Exacerbation Advisory Panel. Pharmacological strategies for self-management of asthma exacerbations. Eur. Respir. J. 2006, 28, 182-199. [CrossRef]

42. Hasegawa, T.; Ishihara, K.; Takakura, S.; Fujii, H.; Nishimura, T.; Okazaki, M.; Katakami, N.; Umeda, B. Duration of systemic corticosteroids in the treatment of asthma exacerbation; a randomized study. Intern. Med. 2000, 39, 794-797. [CrossRef] [PubMed]

43. Jones, A.M.; Munavvar, M.; Vail, A.; Aldridge, R.E.; Hopkinson, L.; Rayner, C.; O'Driscoll, B.R. Prospective, placebo-controlled trial of 5 vs. 10 days of oral prednisolone in acute adult asthma. Respir. Med. 2002, 96, 950-954. [CrossRef] [PubMed]

44. Chang, A.B.; Clark, R.; Sloots, T.P.; Stone, D.G.; Petsky, H.L.; Thearle, D.; Champion, A.A.; Wheeler, C.; Acworth, J.P. A 5- versus 3-day course of oral corticosteroids for children with asthma exacerbations who are not hospitalised: A randomised controlled trial. Med. J. Aust. 2008, 189, 306-310. [CrossRef] [PubMed]

45. Broersen, L.H.; Pereira, A.M.; Jørgensen, J.O.; Dekkers, O.M. Adrenal insufficiency in corticosteroids use: Systematic review and meta-analysis. J. Clin. Endocrinol. Metab. 2015, 100, 2171-2180. [CrossRef] [PubMed]

46. Walsh, L.J.; Wong, C.A.; Oborne, J.; Cooper, S.; Lewis, S.A.; Pringle, M.; Hubbard, R.; Tattersfield, A.E. Adverse effects of oral corticosteroids in relation to dose in patients with lung disease. Thorax 2001, 56, 279-284. [CrossRef] [PubMed]

47. Lefebvre, P.; Duh, M.S.; Lafeuille, M.H.; Gozalo, L.; Desai, U.; Robitaille, M.N.; Albers, F.; Yancey, S.; Ortega, H.; Forshag, M.; et al. Acute and chronic systemic corticosteroid-related complications in patients with severe asthma. J. Allergy Clin. Immunol. 2015, 136, 1488-1495. [CrossRef] [PubMed]

48. Price, D.B.; Trudo, F.; Voorham, J.; Xu, X.; Kerkhof, M.; Ling Zhi Jie, J.; Tran, T.N. Adverse outcomes from initiation of systemic corticosteroids for asthma: Long-term observational study. J. Asthma. Allergy 2018, 11, 193-204. [CrossRef] 
49. Grossman, J.M.; Gordon, R.; Ranganath, V.K.; Deal, C.; Caplan, L.; Chen, W.; Curtis, J.R.; Furst, D.E.; McMahon, M.; Patkar, N.M.; et al. American College of Rheumatology 2010 recommendations for the prevention and treatment of glucocorticoid-induced osteoporosis. Arthritis Care Res. 2010, 62, 1515-1526. [CrossRef]

50. Richards, R.N. Side effects of short-term oral corticosteroids. J. Cutan. Med. Surg. 2008, 12, 77-81. [CrossRef] [PubMed]

51. O'Byrne, P.M.; Fitz Gerald, J.M.; Bateman, E.D.; Barnes, P.J.; Zhong, N.; Keen, C.; Jorup, C.; Lamarca, R.; Ivanov, S.; Reddel, H.K. Inhaled combined budesonide-formoterol as needed in mild asthma. N. Engl. J. Med. 2018, 378, 1865-1876. [CrossRef] [PubMed]

52. Bateman, E.D.; Reddel, H.K.; O’Byrne, P.M.; Barnes, P.J.; Zhong, N.; Keen, C.; Jorup, C.; Lamarca, R.; Siwek-Posluszna, A.; Fitz Gerald, J.M. As-needed budesonide-formoterol versus maintenance budesonide in mild asthma. N. Engl. J. Med. 2018, 378, 1877-1887. [CrossRef] [PubMed]

53. Hagan, J.B.; Samant, S.A.; Volcheck, G.W.; Li, J.T.; Hagan, C.R.; Erwin, P.J.; Rank, M.A. The risk of asthma exacerbation after reducing inhaled corticosteroids: A systematic review and meta-analysis of randomized controlled trials. Allergy 2014, 69, 510-516. [CrossRef] [PubMed]

54. Lanier, B.Q.; Corren, J.; Lumry, W.; Liu, J.; Fowler-Taylor, A.; Gupta, N. Omalizumab is effective in the long-term control of severe allergic asthma. Ann. Allergy Asthma Immunol. 2003, 91, 154-159. [CrossRef]

55. Hochhaus, G.; Brookman, L.; Fox, H.; Johnson, C.; Matthews, J.; Ren, S.; Deniz, Y. Pharmacodynamics of omalizumab: Implications for optimised dosing strategies and clinical efficacy in the treatment of allergic asthma. Curr. Med. Res. Opin. 2003, 19, 491-498. [CrossRef] [PubMed]

56. Lafeuille, M.H.; Gravel, J.; Zhang, J.; Gorsh, B.; Figliomeni, M.; Lefebvre, P. Association between consistent omalizumab treatment and asthma control. J. Allergy Clin. Immunol. Pract. 2013, 1, 51-57. [CrossRef]

57. Apsangikar, P.; Ghadge, P.; Naik, M.; Nair, S. Randomized comparative clinical study of first global omalizumab biosimilar with innovator product in moderate to severe persistent asthma. J. Assoc. Physicians India. 2020, 68, 61-65.

58. Grossman, H.L.; Schlender, A.; Alperin, P.; Stanley, E.L.; Zhang, J. Modeling the effects of omalizumab over 5 years among patients with moderate-to-severe persistent allergic asthma. Curr. Med. Res. Opin. 2010, 26, 2779-2793. [CrossRef] [PubMed]

59. Pelaia, G.; Gallelli, L.; Romeo, P.; Renda, T.; Busceti, M.T.; Proietto, A.; Grembiale, R.D.; Marsico, S.A.; Maselli, R.; Vatrella, A. Omalizumab decreases exacerbation frequency, oral intake of corticosteroids and peripheral blood eosinophils in atopic patients with uncontrolled asthma. Int. J. Clin. Pharmacol. Ther. 2011, 49, 713-721. [CrossRef] [PubMed]

60. Schumann, C.; Kropf, C.; Wibmer, T.; Rüdiger, S.; Stoiber, K.M.; Thielen, A.; Rottbauer, W.; Kroegel, C. Omalizumab in patients with severe asthma: The XCLUSIVE study. Clin. Respir. J. 2012, 6, 215-227. [CrossRef]

61. Chen, H.C.; Huang, C.D.; Chang, E.; Kuo, H.P. Efficacy of omalizumab (Xolair) in patients with moderate to severe predominately chronic oral steroid dependent asthma in Taiwan: A retrospective, population-based database cohort study. BMC Pulm. Med. 2016, 16, 3. [CrossRef]

62. Lafeuille, M.H.; Dean, J.; Zhang, J.; Duh, M.S.; Gorsh, B.; Lefebvre, P. Impact of omalizumab on emergency-department visits, hospitalizations, and corticosteroid use among patients with uncontrolled asthma. Ann. Allergy Asthma Immunol. 2012, 109, 59-64. [CrossRef] [PubMed]

63. Siergiejko, Z.; Świebocka, E.; Smith, N.; Peckitt, C.; Leo, J.; Peachey, G.; Maykut, R. Oral corticosteroid sparing with omalizumab in severe allergic (IgE-mediated) asthma patients. Curr. Med. Res. Opin. 2011, 27, 2223-2228. [CrossRef] [PubMed]

64. Walker, S.; Monteil, M.; Phelan, K.; Lasserson, T.J.; Walters, E.H. Anti-IgE for chronic asthma in adults and children. Cochrane Database Syst. Rev. 2004, 3, CD003559.

65. Nguyen, V.Q.; Ulrik, C.S. Measures to reduce maintenance therapy with oral corticosteroid in adults with severe asthma. Allergy Asthma Proc. 2016, 37, 125-139. [CrossRef] [PubMed]

66. Molimard, M.; de Blay, F.; Didier, A.; Le Gros, V. Effectiveness of omalizumab (Xolair) in the first patients treated in real-life practice in France. Respir. Med. 2008, 102, 71-76. [CrossRef] [PubMed]

67. Sposato, B.; Scalese, M.; Latorre, M.; Scichilone, N.; Matucci, A.; Milanese, M.; Masieri, S.; Rolla, G.; Steinhilber, G.; Rosati, Y.; et al. Effects of omalizumab in severe asthmatics across ages: A real life Italian experience. Respir. Med. 2016, 119, 141-149. [CrossRef] [PubMed]

68. Molimard, M.; Buhl, R.; Niven, R.; Le Gros, V.; Thielen, A.; Thirlwell, J.; Maykut, R.; Peachey, G. Omalizumab reduces oral corticosteroid use in patients with severe allergic asthma: Real-life data. Respir. Med. 2010, 104, 1381-1385. [CrossRef] [PubMed]

69. Sousa, A.S.; Pereira, A.M.; Fonseca, J.A.; Azevedo, L.F.; Abreu, C.; Arrobas, A.; Calvo, T.; Silvestre, M.J.; Cunha, L.; Falcão, H.; et al. Asthma control and exacerbations in patients with severe asthma treated with omalizumab in Portugal. Rev. Port. Pneumol. 2015, 21, 327-333. [CrossRef]

70. Papaioannou, A.I.; Mplizou, M.; Porpodis, K.; Fouka, E.; Zervas, E.; Samitas, K.; Markatos, M.; Bakakos, P.; Papiris, S.; Gaga, M.; et al. Long-term efficacy and safety of omalizumab in patients with allergic asthma: A real-life study. Allergy Asthma Proc. 2021, 42, 235-242. [CrossRef] [PubMed]

71. Asano, K.; Sumi, K.; Yoshisue, H.; Nakamura, N.; Nagasaki, M.; Sasajima, T.; Matsumoto, H. Real-life safety and efficacy of omalizumab in Japanese patients with severe allergic asthma who were subjected to dosing table revision or expansion: A post-marketing surveillance. Pulm. Pharmacol. Ther. 2020, 64, 101950. [CrossRef] [PubMed]

72. Verhamme, K.M.C.; Lucet, C.; Van Meerhaeghe, A.; Brusselle, G.G.O.; Lambert, M.L. Real-life effectiveness of omalizumab in difficult-to-treat versus severe asthma: A national cohort study in Belgium. ERJ Open Res. 2019, 5, 00253-2018. [CrossRef] [PubMed] 
73. Pace, E.; Ferraro, M.; Bruno, A.; Chiappara, G.; Bousquet, J.; Gjomarkaj, M. Clinical benefits of 7 years of treatment with omalizumab in severe uncontrolled asthmatics. J. Asthma 2011, 48, 387-392. [CrossRef] [PubMed]

74. Reddel, H.; Ware, S.; Marks, G.; Salome, C.; Jenkins, C.; Woolcock, A. Differences between asthma exacerbations and poor asthma control. Lancet 1999, 353, 364-369. [CrossRef]

75. Pauwels, R.A.; Pedersen, S.; Busse, W.W.; Tan, W.C.; Chen, Y.Z.; Ohlsson, S.V.; Ullman, A.; Lamm, C.J.; O’Byrne, P.M.; START Investigators Group. Early intervention with budesonide in mild persistent asthma: A randomised, double-blind trial. Lancet 2003, 361, 1071-1076. [CrossRef]

76. Sturdy, P.M.; Victor, C.R.; Anderson, H.R.; Bland, J.M.; Butland, B.K.; Harrison, B.D.; Peckitt, C.; Taylor, J.C.; Mortality and Severe Morbidity Working Group of the National Asthma Task Force. Psychological, social and health behaviour risk factors for deaths certified as asthma: A national case-control study. Thorax 2002, 57, 1034-1039. [CrossRef]

77. Alvarez, G.G.; Schulzer, M.; Jung, D.; Fitzgerald, J.M. A systematic review of risk factors associated with near-fatal and fatal asthma. Can. Respir. J. 2005, 12, 265-270. [CrossRef]

78. Chang, Y.L.; Ko, H.K.; Lu, M.S.; Chou, C.L.; Su, K.C.; Hsu, C.C.; Chou, K.T.; Chen, T.J.; Perng, D.W.; Chou, Y.C. Independent risk factors for death in patients admitted for asthma exacerbation in Taiwan. NPJ Prim. Care Respir Med. 2020, 30, 7. [CrossRef] [PubMed]

79. Suissa, S.; Blais, L.; Ernst, P. Patterns of increasing beta-agonist use and the risk of fatal or near-fatal asthma. Eur. Respir J. 1994, 7 , 1602-1609. [CrossRef]

80. Roberts, G.; Patel, N.; Levi-Schaffer, F.; Habibi, P.; Lack, G. Food allergy as a risk factor for life-threatening asthma in childhood: A case-controlled study. J. Allergy Clin. Immunol. 2003, 112, 168-174. [CrossRef] [PubMed]

81. Niven, R.; Chung, K.F.; Panahloo, Z.; Blogg, M.; Ayre, G. Effectiveness of omalizumab in patients with inadequately controlled severe persistent allergic asthma: An open-label study. Respir. Med. 2008, 102, 1371-1378. [CrossRef]

82. Kulus, M.; Hébert, J.; Garcia, E.; Fowler Taylor, A.; Fernandez Vidaurre, C.; Blogg, M. Omalizumab in children with inadequately controlled severe allergic (IgE-mediated) asthma. Curr. Med. Res. Opin. 2010, 26, 1285-1293. [CrossRef] [PubMed]

83. Odajima, H.; Ebisawa, M.; Nagakura, T.; Fujisawa, T.; Akasawa, A.; Ito, K.; Doi, S.; Yamaguchi, K.; Katsunuma, T.; Kurihara, K.; et al. Omalizumab in Japanese children with severe allergic asthma uncontrolled with standard therapy. Allergol. Int. 2015, 64, 364-370. [CrossRef] [PubMed]

84. Ledford, D.; Busse, W.; Trzaskoma, B.; Omachi, T.A.; Rosén, K.; Chipps, B.E.; Luskin, A.T.; Solari, P.G. A randomized multicenter study evaluating Xolair persistence of response after long-term therapy. J. Allergy Clin. Immunol. 2017, 140, 162-169.e2. [CrossRef] [PubMed]

85. Rubin, A.S.; Souza-Machado, A.; Andradre-Lima, M.; Ferreira, F.; Honda, A.; Matozo, T.M.; QUALITX Study Investigators. Effect of omalizumab as add-on therapy on asthma-related quality of life in severe allergic asthma: A Brazilian study (QUALITX). J. Asthma 2012, 49, 288-293. [CrossRef] [PubMed]

86. Li, J.; Kang, J.; Wang, C.; Yang, J.; Wang, L.; Kottakis, I.; Humphries, M.; Zhong, N.; China Omalizumab Study Group. Omalizumab improves quality of life and asthma control in chinese patients with moderate to severe asthma: A randomized phase III study. Allergy Asthma Immunol. Res. 2016, 8, 319-328. [CrossRef] [PubMed]

87. Agache, I.; Rocha, C.; Beltran, J.; Song, Y.; Posso, M.; Solà, I.; Alonso-Coello, P.; Akdis, C.; Akdis, M.; Canonica, G.W.; et al. Efficacy and safety of treatment with biologicals (benralizumab, dupilumab and omalizumab) for severe allergic asthma: A systematic review for the EAACI Guidelines-Recommendations on the use of biologicals in severe asthma. Allergy. 2020, 75, 1043-1057. [CrossRef]

88. Teach, S.J.; Gill, M.A.; Togias, A.; Sorkness, C.A.; Arbes, S.J., Jr.; Calatroni, A.; Wildfire, J.J.; Gergen, P.J.; Cohen, R.T.; Pongracic, J.A.; et al. Preseasonal treatment with either omalizumab or an inhaled corticosteroid boost to prevent fall asthma exacerbations. J. Allergy Clin. Immunol. 2015, 136, 1476-1485. [CrossRef]

89. Brusselle, G.; Michils, A.; Louis, R.; Dupont, L.; Van de Maele, B.; Delobbe, A.; Pilette, C.; Lee, C.S.; Gurdain, S.; Vancayzeele, S.; et al. "Real-life" effectiveness of omalizumab in patients with severe persistent allergic asthma: The PERSIST study. Respir. Med. 2009, 103, 1633-1642. [CrossRef]

90. Bhutani, M.; Yang, W.H.; Hébert, J.; de Takacsy, F.; Stril, J.L. The real world effect of omalizumab add on therapy for patients with moderate to severe allergic asthma: The ASTERIX observational study. PLoS ONE 2017, 12, e0183869. [CrossRef]

91. Canonica, G.W.; Rottoli, P.; Bucca, C.; Zappa, M.C.; Michetti, G.; Macciocchi, B.; Caruso, C.; Santus, P.; Bartezaghi, M.; Rigoni, L.; et al. Improvement of patient-reported outcomes in severe allergic asthma by omalizumab treatment: The real life observational PROXIMA study. World Allergy Organ. J. 2018, 11, 33. [CrossRef] [PubMed]

92. Casale, T.B.; Luskin, A.T.; Busse, W.; Zeiger, R.S.; Trzaskoma, B.; Yang, M.; Griffin, N.M.; Chipps, B.E. Omalizumab effectiveness by biomarker status in patients with asthma: Evidence from PROSPERO, a prospective real-world study. J. Allergy Clin. Immunol. Pract. 2019, 7, 156-164.e1. [CrossRef]

93. Humbert, M.; Taillé, C.; Mala, L.; Le Gros, V.; Just, J.; Molimard, M.; STELLAIR investigators. Omalizumab effectiveness in patients with severe allergic asthma according to blood eosinophil count: The STELLAIR study. Eur. Respir J. 2018, 51, 1702523. [CrossRef] [PubMed]

94. Yorgancıoğlu, A.; Öner Erkekol, F.; Mungan, D.; Erdinç, M.; Gemicioğlu, B.; Özşeker, Z.F.; Bayrak Değirmenci, P.; Nayc1, S.; Çilli, A.; Erdenen, F.; et al. Long-term omalizumab treatment: A multicenter, real-life, 5-year trial. Int. Arch. Allergy Immunol. 2018, 176, 225-233. [CrossRef] [PubMed] 
95. Vennera Mdel, C.; Pérez De Llano, L.; Bardagí, S.; Ausin, P.; Sanjuas, C.; González, H.; Gullón, J.A.; Martínez-Moragón, E.; Carretero, J.A.; Vera, E.; et al. Omalizumab therapy in severe asthma: Experience from the Spanish registry-Some new approaches. J. Asthma 2012, 49, 416-422. [CrossRef] [PubMed]

96. Subramaniam, A.; Al-Alawi, M.; Hamad, S.; O'Callaghan, J.; Lane, S.J. A study into efficacy of omalizumab therapy in patients with severe persistent allergic asthma at a tertiary referral centre for asthma in Ireland. QJM 2013, 106, 631-634. [CrossRef] [PubMed]

97. Adachi, M.; Kozawa, M.; Yoshisue, H.; Lee Milligan, K.; Nagasaki, M.; Sasajima, T.; Miyamoto, T.; Ohta, K. Real-world safety and efficacy of omalizumab in patients with severe allergic asthma: A long-term post-marketing study in Japan. Respir. Med. 2018, 141, 56-63. [CrossRef] [PubMed]

98. Kawamatawong, T.; Poachanukoon, O.; Boonsiri, C.; Saengasapaviriya, A.; Sittipunt, C.; Chantaphakul, H.; Maneechotesuwan, K.; Ngamchanyaporn, P.; Piyavechviratana, K.; Yongjaiyut, P.; et al. Long-term effectiveness of omalizumab treatment in Thai severe asthmatic patients: A real-life experience. Asian Pac. J. Allergy Immunol. 2018, 36, 238-243.

99. Molimard, M.; Mala, L.; Bourdeix, I.; Le Gros, V. Observational study in severe asthmatic patients after discontinuation of omalizumab for good asthma control. Respir. Med. 2014, 108, 571-576. [CrossRef] [PubMed]

100. Kupryś-Lipińska, I.; Kuna, P. Loss of asthma control after cessation of omalizumab treatment: Real life data. Postepy. Dermatol Alergol. 2014, 31, 1-5. [CrossRef]

101. Leatherman, J. Mechanical ventilation for severe asthma. Chest 2015, 147, 1671-1680. [CrossRef]

102. Manser, R.; Reid, D.; Abramson, M. Corticosteroids for acute severe asthma in hospitalised patients. Cochrane Database Syst. Rev. 2000, 1, CD001740. [CrossRef] [PubMed]

103. Rowe, B.H.; Spooner, C.H.; Ducharme, F.M.; Bretzlaff, J.A.; Bota, G.W. Corticosteroids for preventing relapse following acute exacerbations of asthma. Cochrane Database Syst. Rev. 2007, 3, CD000195. [CrossRef] [PubMed]

104. Kirkland, S.W.; Cross, E.; Campbell, S.; Villa-Roel, C.; Rowe, B.H. Intramuscular versus oral corticosteroids to reduce relapses following discharge from the emergency department for acute asthma. Cochrane Database Syst. Rev. 2018, 6, CD012629. [CrossRef] [PubMed]

105. Edmonds, M.L.; Milan, S.J.; Camargo, C.A., Jr.; Pollack, C.V.; Rowe, B.H. Early use of inhaled corticosteroids in the emergency department treatment of acute asthma. Cochrane Database Syst. Rev. 2012, 12, CD002308. [CrossRef]

106. Kearns, N.; Maijers, I.; Harper, J.; Beasley, R.; Weatherall, M. Inhaled corticosteroids in acute asthma: A systemic review and meta-analysis. J. Allergy Clin. Immunol. Pract. 2020, 8, 605-617.e6. [CrossRef]

107. Balanag, V.M.; Yunus, F.; Yang, P.C.; Jorup, C. Efficacy and safety of budesonide/formoterol compared with salbutamol in the treatment of acute asthma. Pulm. Pharmacol. Ther. 2006, 19, 139-147. [CrossRef]

108. Rowe, B.H.; Bretzlaff, J.A.; Bourdon, C.; Bota, G.W.; Camargo, C.A., Jr. Magnesium sulfate for treating exacerbations of acute asthma in the emergency department. Cochrane Database Syst. Rev. 2000, 2, CD001490. [CrossRef] [PubMed]

109. Goodacre, S.; Cohen, J.; Bradburn, M.; Gray, A.; Benger, J.; Coats, T.; 3Mg Research Team. Intravenous or nebulised magnesium sulphate versus standard therapy for severe acute asthma (3Mg trial): A double-blind, randomised controlled trial. Lancet Respir Med. 2013, 1, 293-300. [CrossRef]

110. Griffiths, B.; Kew, K.M. Intravenous magnesium sulfate for treating children with acute asthma in the emergency department Cochrane Database Syst. Rev. 2016, 4, CD011050.

111. Knightly, R.; Milan, S.J.; Hughes, R.; Knopp-Sihota, J.A.; Rowe, B.H.; Normansell, R.; Powell, C. Inhaled magnesium sulfate in the treatment of acute asthma. Cochrane Database Syst. Rev. 2017, 11, CD003898. [CrossRef] [PubMed]

112. Normansell, R.; Sayer, B.; Waterson, S.; Dennett, E.J.; Del Forno, M.; Dunleavy, A. Antibiotics for exacerbations of asthma. Cochrane Database Syst. Rev. 2018, 6, CD002741. [CrossRef] [PubMed]

113. Odajima, H.; Ebisawa, M.; Nagakura, T.; Fujisawa, T.; Akasawa, A.; Ito, K.; Doi, S.; Yamaguchi, K.; Katsunuma, T.; Kurihara, K.; et al. Long-term safety, efficacy, pharmacokinetics and pharmacodynamics of omalizumab in children with severe uncontrolled asthma. Allergol. Int. 2017, 66, 106-115. [CrossRef] [PubMed]

114. Corren, J.; Casale, T.; Deniz, Y.; Ashby, M. Omalizumab, a recombinant humanized anti-IgE antibody, reduces asthma-related emergency room visits and hospitalizations in patients with allergic asthma. J. Allergy Clin. Immunol. 2003, 111, 87-90. [CrossRef] [PubMed]

115. Cazzola, M.; Camiciottoli, G.; Bonavia, M.; Gulotta, C.; Ravazzi, A.; Alessandrini, A.; Caiaffa, M.F.; Berra, A.; Schino, P.; Di Napoli, P.L.; et al. Italian real-life experience of omalizumab. Respir. Med. 2010, 104, 1410-1416. [CrossRef] [PubMed]

116. Ke, X.; Kavati, A.; Wertz, D.; Huang, Q.; Wang, L.; Willey, V.J.; Stephenson, J.J.; Ortiz, B.; Panettieri, R.A., Jr.; Corren, J. Real-world clinical characteristics, treatment patterns, and exacerbations in US patients With asthma newly treated with omalizumab. Clin. Ther. 2018, 40, 1140-1158.e4. [CrossRef] [PubMed]

117. Al-Ahmad, M.; Arifhodzic, N.; Nurkic, J.; Maher, A.; Rodriguez-Bouza, T.; Al-Ahmed, N.; Sadek, A.; Jusufovic, E. “Real-life” efficacy and safety aspects of 4-year omalizumab treatment for asthma. Med. Princ. Pract. 2018, 27, 260-266. [CrossRef] [PubMed]

118. Lee, J.H.; Lee, H.Y.; Jung, C.G.; Ban, G.Y.; Shin, Y.S.; Ye, Y.M.; Nahm, D.H.; Park, H.S. Therapeutic effect of omalizumab in severe asthma: A real-world study in Korea. Allergy Asthma Immunol. Res. 2018, 10, 121-130. [CrossRef]

119. Chiner, E.; Fernández-Fabrellas, E.; Landete, P.; Novella, L.; Ramón, M.; Sancho-Chust, J.N.; Senent, C.; Berraondo, J. Comparison of costs and clinical outcomes between hospital and outpatient administration of omalizumab in patients with severe uncontrolled asthma. Arch. Bronconeumol. 2016, 52, 211-216. [CrossRef] 
120. Yoshikawa, H.; Iwata, M.; Matsuzaki, H.; Ono, R.; Murakami, Y.; Taba, N.; Honjo, S.; Motomura, C.; Odajima, H. Impact of omalizumab on medical cost of childhood asthma in Japan. Pediatr. Int. 2016, 58, 425-428. [CrossRef]

121. Reed, C.E. Asthma in the elderly: Diagnosis and management. J. Allergy Clin. Immunol. 2010, 126, 681-687. [CrossRef]

122. Foster, J.M.; McDonald, V.M.; Guo, M.; Reddel, H.K. "I have lost in every facet of my life": The hidden burden of severe asthma. Eur. Respir J. 2017, 50, 1700765. [CrossRef] [PubMed]

123. Waljee, A.K.; Rogers, M.A.; Lin, P.; Singal, A.G.; Stein, J.D.; Marks, R.M.; Ayanian, J.Z.; Nallamothu, B.K. Short term use of oral corticosteroids and related harms among adults in the United States: Population based cohort study. BMJ 2017, 357, j1415 [CrossRef] [PubMed]

124. Bardelas, J.; Figliomeni, M.; Kianifard, F.; Meng, X. A 26-week, randomized, double-blind, placebo-controlled, multicenter study to evaluate the effect of omalizumab on asthma control in patients with persistent allergic asthma. J. Asthma 2012, 49, 144-152. [CrossRef] [PubMed]

125. Hanania, N.A.; Alpan, O.; Hamilos, D.L.; Condemi, J.J.; Reyes-Rivera, I.; Zhu, J.; Rosen, K.E.; Eisner, M.D.; Wong, D.A.; Busse, W. Omalizumab in severe allergic asthma inadequately controlled with standard therapy: A randomized trial. Ann. Intern. Med. 2011, 154, 573-582. [CrossRef] [PubMed]

126. Sthoeger, Z.M.; Eliraz, A.; Asher, I.; Berkman, N.; Elbirt, D. The beneficial effects of Xolair (omalizumab) as add-on therapy in patients with severe persistent asthma who are inadequately controlled despite best available treatment (GINA 2002 step IV)-The Israeli arm of the INNOVATE study. Isr. Med. Assoc. J. 2007, 9, 472-475. [PubMed]

127. Buhl, R.; Solèr, M.; Matz, J.; Townley, R.; O’Brien, J.; Noga, O.; Champain, K.; Fox, H.; Thirlwell, J.; Della Cioppa, G. Omalizumab provides long-term control in patients with moderate-to-severe allergic asthma. Eur. Respir J. 2002, 20, 73-78. [CrossRef] [PubMed]

128. Maurer, M.; Altrichter, S.; Bieber, T.; Biedermann, T.; Bräutigam, M.; Seyfried, S.; Brehler, R.; Grabbe, J.; Hunzelmann, N.; Jakob, T.; et al. Efficacy and safety of omalizumab in patients with chronic urticaria who exhibit IgE against thyroperoxidase. J. Allergy Clin. Immunol. 2011, 128, 202-209.e5. [CrossRef]

129. Kaplan, A.; Ledford, D.; Ashby, M.; Canvin, J.; Zazzali, J.L.; Conner, E.; Veith, J.; Kamath, N.; Staubach, P.; Jakob, T.; et al. Omalizumab in patients with symptomatic chronic idiopathic/spontaneous urticaria despite standard combination therapy. $J$. Allergy Clin. Immunol. 2013, 132, 101-109. [CrossRef] [PubMed]

130. Casale, T.B.; Bernstein, J.A.; Maurer, M.; Saini, S.S.; Trzaskoma, B.; Chen, H.; Grattan, C.E.; Gimenéz-Arnau, A.; Kaplan, A.P.; Rosén, K. Similar efficacy with omalizumab in chronic idiopathic/spontaneous urticaria despite different background therapy. $J$. Allergy Clin. Immunol. Pract. 2015, 3, 743-750.e1. [CrossRef]

131. Kaplan, A.P.; Joseph, K.; Maykut, R.J.; Geba, G.P.; Zeldin, R.K. Treatment of chronic autoimmune urticaria with omalizumab. J. Allergy Clin. Immunol. 2008, 122, 569-573. [CrossRef]

132. Andorf, S.; Purington, N.; Block, W.M.; Long, A.J.; Tupa, D.; Brittain, E.; Rudman Spergel, A.; Desai, M.; Galli, S.J.; Nadeau, K.C.; et al. Anti-IgE treatment with oral immunotherapy in multifood allergic participants: A double-blind, randomised, controlled trial. Lancet Gastroenterol. Hepatol. 2018, 3, 85-94. [CrossRef]

133. Kamin, W.; Kopp, M.V.; Erdnuess, F.; Schauer, U.; Zielen, S.; Wahn, U. Safety of anti-IgE treatment with omalizumab in children with seasonal allergic rhinitis undergoing specific immunotherapy simultaneously. Pediatr. Allergy Immunol. 2010, 21 Pt 2, e160-e165. [CrossRef] [PubMed]

134. Varghese, M.; Lieberman, P. The effects of repeat omalizumab administration on skin test positivity and the assessment of the safety of administration in patients with positive skin tests to mouse antigen. Allergy Asthma Proc. 2007, 28, 320-323. [CrossRef] [PubMed]

135. Cruz, A.A.; Lima, F.; Sarinho, E.; Ayre, G.; Martin, C.; Fox, H.; Cooper, P.J. Safety of anti-immunoglobulin E therapy with omalizumab in allergic patients at risk of geohelminth infection. Clin. Exp. Allergy 2007, 37, 197-207. [CrossRef]

136. Berger, W.; Gupta, N.; McAlary, M.; Fowler-Taylor, A. Evaluation of long-term safety of the anti-IgE antibody, omalizumab, in children with allergic asthma. Ann. Allergy Asthma Immunol. 2003, 91, 182-188. [CrossRef]

137. Milgrom, H.; Fowler-Taylor, A.; Vidaurre, C.F.; Jayawardene, S. Safety and tolerability of omalizumab in children with allergic (IgE-mediated) asthma. Curr. Med. Res. Opin. 2011, 27, 163-169. [CrossRef]

138. Somerville, L.; Bardelas, J.; Viegas, A.; D'Andrea, P.; Blogg, M.; Peachey, G. Immunogenicity and safety of omalizumab in pre-filled syringes in patients with allergic (IgE-mediated) asthma. Curr. Med. Res. Opin. 2014, 30, 59-66. [CrossRef]

139. Klyucheva, M.; von Berg, A.; Gappa, M.; Suerbaum, C.; Berdel, D. Omalizumab therapy in adolescents with severe allergic asthma-Results of a post-marketing surveillance. Pneumologie 2013, 67, 233-237.

140. Ohta, K.; Yamamoto, M.; Sato, N.; Ikeda, K.; Miyamoto, T. One year treatment with omalizumab is effective and well tolerated in Japanese Patients with moderate-to-severe persistent asthma. Allergol. Int. 2010, 59, 167-174.

141. Kornmann, O.; Watz, H.; Fuhr, R.; Krug, N.; Erpenbeck, V.J.; Kaiser, G. Omalizumab in patients with allergic (IgE-mediated) asthma and IgE/bodyweight combinations above those in the initially approved dosing table. Pulm. Pharmacol. Ther. 2014, 28, 149-153. [CrossRef]

142. Li, L.; Wang, Z.; Cui, L.; Xu, Y.; Guan, K.; Zhao, B. Anaphylactic risk related to omalizumab, benralizumab, reslizumab, mepolizumab, and dupilumab. Clin. Transl. Allergy. 2021, 11, e12038. [CrossRef] [PubMed]

143. Pacheco-Galván, A.; Hinojosa-Macías, M.; Hurtado-Barbudo, B.; González-Cervera, J.; Sueiro-Bendito, A. Analysis of asthma control and quality of life in severe allergic asthmatics under treatment with anti-IgE.; omalizumab. Med. Clin. 2009, 133, 460-463. [CrossRef] [PubMed] 
144. Korn, S.; Schumann, C.; Kropf, C.; Stoiber, K.; Thielen, A.; Taube, C.; Buhl, R. Effectiveness of omalizumab in patients 50 years and older with severe persistent allergic asthma. Ann. Allergy Asthma Immunol. 2010, 105, 313-319. [CrossRef] [PubMed]

145. Mota, D.; Rama, T.A.; Severo, M.; Moreira, A. Potential cancer risk with omalizumab? A disproportionality analysis of the WHO's VigiBase pharmacovigilance database. Allergy 2021, 76, 3209-3211. [CrossRef]

146. Nakamura, N.; Kashitani, Y.; Yoshisue, H.; Nagasaki, M.; Sasajima, T. Real-life long-term safety and effectiveness of omalizumab in Japanese pediatric patients with severe allergic asthma: A post-marketing surveillance. Allergol. Int. 2021, 70, 319-326. [CrossRef]

147. Di Bona, D.; Fiorino, I.; Taurino, M.; Frisenda, F.; Minenna, E.; Pasculli, C.; Kourtis, G.; Rucco, A.S.; Nico, A.; Albanesi, M.; et al Long-term "real-life" safety of omalizumab in patients with severe uncontrolled asthma: A nine-year study. Respir. Med. 2017, 130, 55-60. [CrossRef]

148. Gibson, P.G.; Reddel, H.; McDonald, V.M.; Marks, G.; Jenkins, C.; Gillman, A.; Upham, J.; Sutherland, M.; Rimmer, J.; Thien, F.; et al. Effectiveness and response predictors of omalizumab in a severe allergic asthma population with a high prevalence of comorbidities: The Australian xolair registry. Intern. Med. J. 2016, 46, 1054-1062. [CrossRef]

149. Sousa, J.; Taborda-Barata, L.; Monteiro, C. Biological therapy-associated adverse reactions in asthma: Analysis of reporting to the Portuguese pharmacovigilance system. Expert Opin. Drug Saf. 2020, 19, 99-106. [CrossRef]

150. Vieira, T.; de Oliveira, J.F.; da Graça Castel-Branco, M. Short and long-term quality of life and asthma control with omalizumab therapy in a real life setting in Portugal. Allergol. Immunopathol. 2014, 42, 3-10. [CrossRef]

151. Tat, T.S.; Cilli, A. Evaluation of long-term safety and efficacy of omalizumab in elderly patients with uncontrolled allergic asthma. Ann. Allergy Asthma Immunol. 2016, 117, 546-549. [CrossRef]

152. Shitrit, D.; Talker, O.; Metabichek, A.; Yaakovi, I. Omalizumab treatment in patients with asthma: Summary of meir medical center experience with 47 patients. Harefuah 2012, 151, 216-219, 254, 253. [PubMed]

153. López Tiro, J.J.; Contreras, E.A.; del Pozo, M.E.; Gómez Vera, J.; Larenas Linnemann, D. Real life study of three years omalizumab in patients with difficult-to-control asthma. Allergol. Immunopathol. 2015, 43, 120-126. [CrossRef] [PubMed]

154. Rottem, M. Omalizumab reduces corticosteroid use in patients with severe allergic asthma: Real-life experience in Israel. $J$. Asthma 2012, 49, 78-82. [CrossRef] [PubMed]

155. Büyüköztürk, S.; Gelincik, A.; Demirtürk, M.; Kocaturk, E.; Colakoğlu, B.; Dal, M. Omalizumab markedly improves urticaria activity scores and quality of life scores in chronic spontaneous urticaria patients: A real life survey. J. Dermatol. 2012, 39, 439-442. [CrossRef] [PubMed]

156. Romano, C.; Sellitto, A.; De Fanis, U.; Balestrieri, A.; Savoia, A.; Abbadessa, S.; Astarita, C.; Lucivero, G. Omalizumab for difficult-to-treat dermatological conditions: Clinical and immunological features from a retrospective real-life experience. Clin. Drug Investig. 2015, 35, 159-168. [CrossRef]

157. Licari, A.; Castagnoli, R.; Denicolò, C.; Rossini, L.; Seminara, M.; Sacchi, L.; Testa, G.; De Amici, M.; Marseglia, G.L.; Omalizumab in Childhood Asthma Italian Study Group. Omalizumab in children with severe allergic asthma: The Italian real-life experience. Curr. Respir Med. Rev. 2017, 13, 36-42. [CrossRef]

158. Türk, M.; Bahçecioğlu, S.N.; Tutar, N.; Oymak, F.S.; Gülmez, İ.; Yılmaz, İ. Omalizumab treatment for atopic severe persistant asthma: A single-center, long-term, real-life experience with 38 patients. Turk. Thorac. J. 2018, 19, 187-192. [CrossRef]

159. Al-Ahmad, M.; Nurkic, J.; Maher, A.; Arifhodzic, N.; Jusufovic, E. Tolerability of omalizumab in asthma as a major compliance factor: 10-year follow up. Open Access. Maced. J. Med. Sci. 2018, 6, 1839-1844. [CrossRef]

160. Giubergia, V.; Ramírez Farías, M.J.; Pérez, V.; Crespi, N.; Castaños, C. Clinical impact of omalizumab treatment in children with severe asthma: Report of a local experience. Arch. Argent Pediatr. 2019, 117, e115-e120.

161. Singh, H.; Peters, J.I.; Kaur, Y.; Maselli, D.J.; Diaz, J.D. Long-term evaluation of response to omalizumab therapy in real life by a novel multimodular approach: The real-life effectiveness of omalizumab therapy (REALITY) study. Ann. Allergy Asthma Immunol. 2019, 123, 476-482.e1. [CrossRef]

162. Abuzakouk, M.; Ghorab, O.K.H.A.; Wahla, A.S.; Zoumot, Z.; Nasir, M.; Grandon, D.; Uzbeck, M.H.; Salvo, F.; Shafiq, I. Efficacy and safety of biologic agents in chronic urticaria, asthma and atopic dermatitis-A real-life experience. Open Respir. Med. J. 2020 14, 99-106. [CrossRef] [PubMed]

163. Zhang, M.; Jin, M.; Zhou, X.; Lin, J.; Liu, X.; Liu, C.; Huang, M.; Wang, W.; Chen, L.; Huang, Y.; et al. Effectiveness of omalizumab in patients with severe allergic asthma: A retrospective study in China. Respir. Med. 2021, 186, 106522. [CrossRef] [PubMed]

164. Nieto García, A.; Garriga-Baraut, T.; Plaza Martín, A.M.; Nieto Cid, M.; Torres Borrego, J.; Folqué Giménez, M.D.M.; Lozano Blasco, J.; Bosque García, M.; Moreno-Galarraga, L.; Tortajada-Girbés, M.; et al. Omalizumab outcomes for up to 6 years in pediatric patients with severe persistent allergic asthma. Pediatr. Allergy Immunol. 2021, 32, 980-991. [CrossRef] [PubMed]

165. Braunstahl, G.J.; Canvin, J.; Peachey, G.; Chen, C.W.; Georgiou, P. Healthcare resource utilization in patients receiving omalizumab for allergic asthma in a real-world setting. Biol. Ther. 2014, 4, 57-67. [CrossRef]

166. Gouder, C.; West, L.M.; Montefort, S. The real-life clinical effects of 52 weeks of omalizumab therapy for severe persistent allergic asthma. Int. J. Clin. Pharm. 2015, 37, 36-43. [CrossRef]

167. Jachiet, M.; Samson, M.; Cottin, V.; Kahn, J.E.; Le Guenno, G.; Bonniaud, P.; Devilliers, H.; Bouillet, L.; Gondouin, A.; Makhlouf, F.; et al. Anti-IgE monoclonal antibody (omalizumab) in refractory and relapsing eosinophilic granulomatosis with polyangiitis (churg-strauss): Data on seventeen patients. Arthritis Rheumatol. 2016, 68, 2274-2282. [CrossRef] 
168. Lowe, P.J.; Renard, D. Omalizumab decreases IgE production in patients with allergic (IgE-mediated) asthma; PKPD analysis of a biomarker, total IgE. Br. J. Clin. Pharmacol. 2011, 72, 306-320. [CrossRef]

169. Tajiri, T.; Matsumoto, H.; Gon, Y.; Ito, R.; Hashimoto, S.; Izuhara, K.; Suzukawa, M.; Ohta, K.; Ono, J.; Ohta, S.; et al. Utility of serum periostin and free IgE levels in evaluating responsiveness to omalizumab in patients with severe asthma. Allergy 2016, 71, 1472-1479. [CrossRef]

170. Chipps, B.E.; Zeiger, R.S.; Luskin, A.T.; Busse, W.W.; Trzaskoma, B.L.; Antonova, E.N.; Pazwash, H.; Limb, S.L.; Solari, P.G.; Griffin, N.M.; et al. Baseline asthma burden, comorbidities, and biomarkers in omalizumab-treated patients in PROSPERO. Ann. Allergy Asthma Immunol. 2017, 119, 524-532.e2. [CrossRef]

171. Hanania, N.A.; Wenzel, S.; Rosén, K.; Hsieh, H.J.; Mosesova, S.; Choy, D.F.; Lal, P.; Arron, J.R.; Harris, J.M.; Busse, W. Exploring the effects of omalizumab in allergic asthma: An analysis of biomarkers in the EXTRA study. Am. J. Respir Crit. Care Med. 2013, 187, 804-811. [CrossRef]

172. Caminati, M.; Vianello, A.; Chieco Bianchi, F.; Festi, G.; Guarnieri, G.; Marchi, M.R.; Micheletto, C.; Olivieri, M.; Tognella, S.; Guerriero, M.; et al. Relevance of TH2 markers in the assessment and therapeutic management of severe allergic asthma: A real-life perspective. J. Investig. Allergol. Clin. Immunol. 2020, 30, 35-41. [CrossRef] [PubMed]

173. Kavati, A.; Zhdanava, M.; Ortiz, B.; Lecocq, J.; Schiffman, B.; Pilon, D.; Ho, H.; Lefebvre, P.; Stone, B. Retrospective study on the association of biomarkers with real-world outcomes of omalizumab-treated patients with allergic asthma. Clin. Ther. 2019, 41, 1956-1971. [CrossRef] [PubMed]

174. Novosad, J.; Krčmová, I.; Bartoš, V.; Drahošová, M.; Vaník, P.; Růžičková-Kirchnerová, O.; Teřl, M.; Krejsek, J. Serum periostin levels in asthma patients in relation to omalizumab therapy and presence of chronic rhinosinusitis with nasal polyps. Postepy. Dermatol. Alergol. 2020, 37, 240-249. [CrossRef] [PubMed]

175. Hachim, M.Y.; Elemam, N.M.; Ramakrishnan, R.K.; Hachim, I.Y.; Salameh, L.; Mahboub, B.; Al Heialy, S.; Halwani, R.; Hamoudi, R.; Hamid, Q. Confounding patient factors affecting the proper interpretation of the periostin level as a biomarker in asthma development. J. Asthma Allergy 2020, 13, 23-37. [CrossRef]

176. Walter, S.; Ho, J.; Alvarado, R.; Rimmer, J.; Campbell, R.; Kalish, L.; Sacks, R.; Harvey, R.J. Effect of monoclonal antibody drug therapy on mucosal biomarkers in airway disease: A systematic review. Clin. Exp. Allergy 2020, 50, 1212-1222. [CrossRef]

177. Brooks, E.A.; Massanari, M.; Hanania, N.A.; Weiner, D.J. Cost-effectiveness of fractional exhaled nitric oxide (FeNO) measurement in predicting response to omalizumab in asthma. Clinicoecon Outcomes Res. 2019, 11, 301-307. [CrossRef]

178. Zhang, Q.; Li, H.; Gao, S.; Wang, J.; Li, C.; Shu, J.; Lin, J. CD3E as a new predictive biomarker of response to omalizumab treatment in asthma patients: Evidence from bioinformatic analysis. Int. Immunopharmacol. 2021, 93, 107423. [CrossRef]

179. Mauri, P.; Riccio, A.M.; Rossi, R.; Di Silvestre, D.; Benazzi, L.; De Ferrari, L.; Dal Negro, R.W.; Holgate, S.T.; Canonica, G.W. Proteomics of bronchial biopsies: Galectin-3 as a predictive biomarker of airway remodelling modulation in omalizumab-treated severe asthma patients. Immunol. Lett. 2014, 162 Pt A, 2-10. [CrossRef]

180. Riccio, A.M.; Mauri, P.; De Ferrari, L.; Rossi, R.; Di Silvestre, D.; Benazzi, L.; Chiappori, A.; Dal Negro, R.W.; Micheletto, C.; Canonica, G.W. Galectin-3: An early predictive biomarker of modulation of airway remodeling in patients with severe asthma treated with omalizumab for 36 months. Clin. Transl. Allergy 2017, 7, 6. [CrossRef]

181. Bulut, I.; Ozseker, Z.F.; Coskun, A.; Serteser, M.; Unsal, I. Pregnancy-associated plasma protein-A (PAPP-A) levels in patients with severe allergic asthma are reduced by omalizumab. J. Asthma 2018, 55, 1116-1121. [CrossRef]

182. Weckmann, M.; Bahmer, T.; Bülow Sand, J.M.; Rank Rønnow, S.; Pech, M.; Vermeulen, C.; Faiz, A.; Leeming, D.J.; Karsdal, M.A.; Lunding, L.; et al. COL4A3 is degraded in allergic asthma and degradation predicts response to anti-IgE therapy. Eur. Respir J. 2021, 58, 2003969. [CrossRef] [PubMed]

183. Domingo, C.; Moreno, A.; José Amengual, M.; Montón, C.; Suárez, D.; Pomares, X. Omalizumab in the management of oral corticosteroid-dependent IGE-mediated asthma patients. Curr. Med. Res. Opin. 2011, 27, 45-53. [CrossRef] [PubMed]

184. Padullés Zamora, N.; Comas Sugrañes, D.; Méndez Cabaleiro, N.; Figueras Suriol, A.; Jodar Masanes, R. Retrospective analysis of omalizumab in patients with severe allergic asthma. Farm Hosp. 2013, 37, 399-405. [PubMed]

185. de Llano, L.P.; Vennera Mdel, C.; Álvarez, F.J.; Medina, J.F.; Borderías, L.; Pellicer, C.; González, H.; Gullón, J.A.; MartínezMoragón, E.; Sabadell, C.; et al. Effects of omalizumab in non-atopic asthma: Results from a Spanish multicenter registry. J. Asthma 2013, 50, 296-301. [CrossRef]

186. Sztafińska, A.; Jerzyńska, J.; Stelmach, W.; Woicka-Kolejwa, K.; Stelmach, I. Quality of life in asthmatic children and their caregivers after two-year treatment with omalizumab, a real-life study. Postepy. Dermatol. Alergol. 2017, 34, 439-447. [CrossRef]

187. Aguilar-Hinojosa, N.K.; Sánchez-Tec, G. Quality of life in patients with allergic asthma on treatment with omalizumab. Rev. Alerg. Mex. 2018, 65, 349-356.

188. Przybyszowski, M.; Paciorek, K.; Zastrzeżyńska, W.; Gawlewicz-Mroczka, A.; Trojan-Królikowska, A.; Orłowska, A.; Soja, J.; Pawlik, W.; Sładek, K. Influence of omalizumab therapy on airway remodeling assessed with high-resolution computed tomography (HRCT) in severe allergic asthma patients. Adv. Respir. Med. 2018, 86, 282-290. [CrossRef]

189. Heffler, E.; Saccheri, F.; Bartezaghi, M.; Canonica, G.W. Effectiveness of omalizumab in patients with severe allergic asthma with and without chronic rhinosinusitis with nasal polyps: A PROXIMA study post hoc analysis. Clin. Transl. Allergy 2020, 10, 25. [CrossRef] 
190. Dal Negro, R.W.; Guerriero, M.; Micheletto, C.; Tognella, S.; Visconti, M. Changes in total IgE plasma concentration measured at the third month during anti-IgE treatment predict future exacerbation rates in difficult-to-treat atopic asthma: A pilot study. J. Asthma 2011, 48, 437-441. [CrossRef]

191. Menzella, F.; Facciolongo, N.; Piro, R.; Formisano, D.; Roggeri, A.; Simonazzi, A.; Castagnetti, C.; Carbonelli, C.; Zucchi, L. Clinical and pharmacoeconomic aspects of omalizumab: A 4-year follow-up. Ther. Adv. Respir Dis. 2012, 6, 87-95. [CrossRef]

192. Hoshino, M.; Ohtawa, J. Effects of adding omalizumab, an anti-immunoglobulin E antibody, on airway wall thickening in asthma. Respiration 2012, 83, 520-528. [CrossRef] [PubMed]

193. Özgür, E.S.; Özge, C.; Ïlvan, A.; Nayc1, S.A. Assessment of long-term omalizumab treatment in patients with severe allergic asthma long-term omalizumab treatment in severe asthma. J. Asthma 2013, 50, 687-694. [CrossRef] [PubMed]

194. Caminati, M.; Senna, G.; Chieco Bianchi, F.; Marchi, M.R.; Vianello, A.; Micheletto, C.; Pomari, C.; Tognella, S.; Savoia, F.; Mirisola, V.; et al. Omalizumab management beyond clinical trials: The added value of a network model. Pulm. Pharmacol. Ther. 2014, 29, 74-79. [CrossRef] [PubMed]

195. Mansur, A.H.; Srivastava, S.; Mitchell, V.; Sullivan, J.; Kasujee, I. Longterm clinical outcomes of omalizumab therapy in severe allergic asthma: Study of efficacy and safety. Respir. Med. 2017, 124, 36-43. [CrossRef] [PubMed]

196. Pelaia, C.; Calabrese, C.; Barbuto, S.; Busceti, M.T.; Preianò, M.; Gallelli, L.; Savino, R.; Vatrella, A.; Pelaia, G. Omalizumab lowers asthma exacerbations, oral corticosteroid intake and blood eosinophils: Results of a 5-YEAR single-centre observational study. Pulm. Pharmacol. Ther. 2019, 54, 25-30. [CrossRef]

197. Hutyrová, B.; Bystroň, J.; Czech Anti-IgE Registry Collaborators. The effect of omalizumab treatment on severe allergic asthma and allergic comorbidities: Real-life experience from the Czech Anti-IgE Registry. Postepy. Dermatol. Alergol. 2018, 35, 510-515. [CrossRef]

198. Jung, J.W.; Park, H.S.; Park, C.S.; Cho, S.H.; Choi, I.S.; Moon, H.B.; Kwon, S.S.; Yoon, H.J.; Park, J.W.; Lee, J.M.; et al. Effect of omalizumab as add-on therapy to Quality of Life Questionnaire for Korean Asthmatics (KAQLQ) in Korean patients with severe persistent allergic asthma. Korean J. Intern. Med. 2021, 36, 1001-1013. [CrossRef]

199. Folqué, M.M.; Lozano, J.; Riggioni, C.; Piquer, M.; Álvaro, M.; Machinena, A.; Giner, M.T.; Domínguez, O.; Jiménez-Feijoo, R.M.; Dias da Costa, M.; et al. 'Real-life' experience in asthmatic children treated with omalizumab up to six-years follow-up. Allergol. Immunopathol. 2019, 47, 336-341. [CrossRef]

200. Oliveira, M.J.; Vieira, M.; Coutinho, D.; Ladeira, I.; Pascoal, I.; Ferreira, J.; da Silva, J.M.; Carvalho, A.; Lima, R. Severe asthma in obese patients: Improvement of lung function after treatment with omalizumab. Pulmonology 2019, 25, 15-20. [CrossRef]

201. Hanania, N.A.; Fortis, S.; Haselkorn, T.; Gupta, S.; Mumneh, N.; Yoo, B.; Holweg, C.T.J.; Chipps, B.E. Omalizumab in asthma with fixed airway obstruction: Post hoc analysis of EXTRA. J. Allergy Clin. Immunol. Pract. 2021, in press. [CrossRef]

202. Chen, M.; Choo, E.; Yoo, B.; Raut, P.; Haselkorn, T.; Pazwash, H.; Holweg, C.T.J.; Hudes, G. No difference in omalizumab efficacy in patients with asthma by number of asthma-related and allergic comorbidities. Ann. Allergy Asthma Immunol. 2021, 126, 666-673. [CrossRef] [PubMed]

203. Busse, W.W.; Humbert, M.; Haselkorn, T.; Ortiz, B.; Trzaskoma, B.L.; Stephenson, P.; Garcia Conde, L.; Kianifard, F.; Holgate, S.T. Effect of omalizumab on lung function and eosinophil levels in adolescents with moderate-to-severe allergic asthma. Ann. Allergy Asthma Immunol. 2020, 124, 190-196. [CrossRef] [PubMed]

204. Shimizu, Y.; Dobashi, K.; Fueki, N.; Fueki, M.; Okada, T.; Tomioka, S.; Makino, S.; Mori, M. Changes of immunomodulatory cytokines associated with omalizumab therapy for severe persistent asthma. J. Biol. Regul. Homeost. Agents 2011, 25, 177-186. [PubMed]

205. Tajiri, T.; Niimi, A.; Matsumoto, H.; Ito, I.; Oguma, T.; Otsuka, K.; Takeda, T.; Nakaji, H.; Inoue, H.; Iwata, T.; et al. Comprehensive efficacy of omalizumab for severe refractory asthma: A time-series observational study. Ann. Allergy Asthma Immunol. 2014, 113, 470-475.e2. [CrossRef]

206. Wu, P.H.; Dong, C.; Xie, J.X.; Zhang, X.X.; Liu, J.; Ouyang, M.; Ma, J.J.; Huang, W.H.; Ou, C.X.; Li, J.; et al. Preliminary clinical observation of omalizumab therapy for moderate to severe asthma. Zhonghua Jie He He Hu Xi Za Zhi 2021, 44, 611-618.

207. Li, J.; Yang, J.; Kong, L.; Huang, Y.; Chen, P.; Yan, X.; Liu, X.; Zho, X.; Liu, J.; Zhu, X.; et al. Efficacy and safety of omalizumab in patients with moderate-to-severe asthma: An analytic comparison of data from randomized controlled trials between Chinese and Caucasians. Asian Pac. J. Allergy Immunol. 2020, 7, 8.

208. Cameli, P.; Perruzza, M.; Salvini, M.; Fui, A.; Cekorja, B.; Refini, R.M.; Sestini, P.; Bargagli, E. Omalizumab treatment in Samter's triad: Case series and review of the literature. Eur. Rev. Med. Pharmacol. Sci. 2019, 23, 8124-8129.

209. Matsuno, O.; Komori, C.; Hang, Y.; Matsumoto, T.; Minamoto, S. Effectiveness of omalizumab in a patient with severe asthma, low serum IgE level, and lack of sensitized allergens induced by oral steroid therapy: The usefulness of impulse oscillation for assessment of omalizumab therapy. J. Asthma 2012, 49, 839-842. [CrossRef]

210. Probst, M.; Gogolka, A.; Krüll, M.; Noga, O. In search of clinically relevant parameters to monitor successful omalizumab therapy in allergic asthma. Allergol. Select 2019, 2, 49-55. [CrossRef]

211. Noga, O.; Hanf, G.; Kunkel, G. Immunological and clinical changes in allergic asthmatics following treatment with omalizumab. Int. Arch. Allergy Immunol. 2003, 131, 46-52. [CrossRef]

212. Noga, O.; Hanf, G.; Kunkel, G.; Kleine-Tebbe, J. Basophil histamine release decreases during omalizumab therapy in allergic asthmatics. Int. Arch. Allergy Immunol. 2008, 146, 66-70. [CrossRef] [PubMed] 
213. Paganin, F.; Mangiapan, G.; Proust, A.; Prudhomme, A.; Attia, J.; Marchand-Adam, S.; Pellet, F.; Milhe, F.; Melloni, B.; Bernady, A.; et al. Lung function parameters in omalizumab responder patients: An interesting tool? Allergy 2017, 72, 1953-1961. [CrossRef] [PubMed]

214. Hendeles, L.; Khan, Y.R.; Shuster, J.J.; Chesrown, S.E.; Abu-Hasan, M. Omalizumab therapy for asthma patients with poor adherence to inhaled corticosteroid therapy. Ann. Allergy Asthma Immunol. 2015, 114, 58-62.e2. [CrossRef] [PubMed]

215. Prieto, L.; Gutiérrez, V.; Colás, C.; Tabar, A.; Pérez-Francés, C.; Bruno, L.; Uixera, S. Effect of omalizumab on adenosine 5'monophosphate responsiveness in subjects with allergic asthma. Int. Arch. Allergy Immunol. 2006, 139, 122-131. [CrossRef] [PubMed]

216. Corren, J.; Wood, R.A.; Patel, D.; Zhu, J.; Yegin, A.; Dhillon, G.; Fish, J.E. Effects of omalizumab on changes in pulmonary function induced by controlled cat room challenge. J. Allergy Clin. Immunol. 2011, 127, 398-405. [CrossRef]

217. Bousquet, J.; Wenzel, S.; Holgate, S.; Lumry, W.; Freeman, P.; Fox, H. Predicting response to omalizumab, an anti-IgE antibody, in patients with allergic asthma. Chest 2004, 125, 1378-1386. [CrossRef]

218. Bousquet, J.; Cabrera, P.; Berkman, N.; Buhl, R.; Holgate, S.; Wenzel, S.; Fox, H.; Hedgecock, S.; Blogg, M.; Cioppa, G.D. The effect of treatment with omalizumab, an anti-IgE antibody, on asthma exacerbations and emergency medical visits in patients with severe persistent asthma. Allergy 2005, 60, 302-308. [CrossRef]

219. Eisner, M.D.; Yegin, A.; Trzaskoma, B. Severity of asthma score predicts clinical outcomes in patients with moderate to severe persistent asthma. Chest 2012, 141, 58-65. [CrossRef]

220. Snelder, S.M.; Weersink, E.J.M.; Braunstahl, G.J. 4-month omalizumab efficacy outcomes for severe allergic asthma: The dutch national omalizumab in asthma registry. Allergy Asthma Clin. Immunol. 2017, 13, 34. [CrossRef]

221. Kallieri, M.; Papaioannou, A.I.; Papathanasiou, E.; Ntontsi, P.; Papiris, S.; Loukides, S. Predictors of response to therapy with omalizumab in patients with severe allergic asthma-A real life study. Postgrad. Med. 2017, 129, 598-604. [CrossRef] 